Płock

e-mail: martyna.klejnowska@gmail.com

\title{
Zasady konstruowania specjalistycznego słownika rosyjsko-polskiego dla celów dydaktycznych (na materiale terminologii papierów wartościowych) ${ }^{1}$
}

Słowa kluczowe: specjalistyczny słownik dydaktyczny, makrostruktura, mikrostruktura, źródła zasobu terminologicznego

\section{Wprowadzenie}

Terminografia dydaktyczna stanowi obok terminografii ogólnej, specjalistycznej oraz tezaurusowej jedną z odmian leksykografii terminologicznej (terminografii). Jest to dział zajmujący się teorią i praktyką konstruowania specjalistycznych słowników dydaktycznych, które są wykorzystywane w szkolnictwie ogólnym i zawodowym. W ostatnich latach można zaobserwować pojawianie się na rynku wydawniczym tego typu prac, jednak ich liczba jest niewielka w porównaniu do słowników terminologicznych o innym przeznaczeniu. Znikome zainteresowanie leksykografów oraz terminografów tworzeniem dzieł terminograficznych o przeznaczeniu dydaktycznym może wynikać z faktu, że brak jak do tej pory w literaturze przedmiotu zasad konstruowania słowników tego typu. Celem niniejszego artykułu jest przedstawienie etapów i zasad konstruowania specjalistycznych słowników dydaktycznych na przykładzie rosyjsko-polskiego słownika papierów wartościowych.

1 Wybrane tezy niniejszego artykułu zostały zaczerpnięte z pracy doktorskiej pt. $Z a$ sady konstruowania specjalistycznego stownika rosyjsko-polskiego dla celów dydaktycznych (terminologia papierów wartościowych), którą obroniłam w czerwcu 2015 r. 


\section{Określenie adresata oraz zakresu tematycznego słownika}

Ustalając ramy zakresu tematycznego słownika, należy w pierwszej kolejności określić dziedzinę (dziedziny), dla której ma on być zbudowany. Papiery wartościowe stanowią pole terminologiczne, czyli spójny wewnętrznie i uporządkowany według kryteriów językowych zbiór terminów. Ponieważ pola terminologiczne są produktami rozwoju określonej dziedziny wiedzy, poza nimi ich elementy albo nie funkcjonują, albo funkcjonują w innym znaczeniu. Wielkość pola terminologicznego jest determinowana stanem wiedzy $\mathrm{w}$ danej dziedzinie, ale przeważanie waha się w granicach od kilkudziesięciu do 150-200 jednostek terminologicznych [Lukszyn, Zmarzer 2006, 56]. Zakładając, że każdy leksykon terminologiczny jest swego rodzaju systemem, który można podzielić na mniejsze zespoły słowne wzajemnie wyznaczające swoje granice, w zależności od jego wielkości można w nim wyróżnić do kilkudziesięciu pól terminologicznych. W przypadku papierów wartościowych leksykonami nadrzędnymi są finanse, giełda oraz handel zagraniczny. W celu dokładnego zorientowania się w powiązaniach wskazanego pola terminologicznego z wymienionymi dziedzinami, należy rozbić wspomniane dziedziny na części składowe - subdyscypliny, które wskażą obszary styczne z wybranym polem terminologicznym.

Nauka o finansach stanowi ściśle zintegrowaną całość w ramach której można wskazać następujące subdyscypliny: finanse globalne i międzynarodowe, finanse publiczne, rządowe i samorządowe: regionalne i lokalne, finanse banków komercyjnych, spółdzielczych i inwestycyjnych wraz z rynkami finansowymi i inżynierią finansową, finanse ubezpieczeń gospodarczych, finanse przedsiębiorstw i finanse gospodarstw domowych [Flejterski, Świecka 2009, 34]. Terminologia papierów wartościowych o charakterze finansowym mieści się w subdyscyplinie, jaką stanowią finanse rynków finansowych [zob. tabela 1.].

Oprócz papierów wartościowych o charakterze finansowym wyróżnia się towarowe papiery wartościowe, które z kolei stanowią przedmiot obrotu na rynkach towarowych. Dziedziną w ramach której występuje terminologia towarowych papierów wartościowych jest handel zagraniczny.

Handel zagraniczny „, wąskim znaczeniu odnosi się do dóbr materialnych sprzedawanych za granicę lub zakupywanych za granicą. W szerokim znaczeniu handel zagraniczny obejmuje obroty majątkowo-kredytowe oraz obroty bieżące, na które, oprócz wymiany towarowej, składają się zakup i sprzedaż za granicę usług, dóbr niematerialnych oraz zobowiązania wynikające z ruchu ludności poza granicę i inne" [Rymarczyk 2012, 17]. 
Tabela 1. Subdyscypliny nauki finansów i obiekty ich badań

\begin{tabular}{|c|c|}
\hline Subdyscyplina & Obiekty (przedmioty) badań \\
\hline $\begin{array}{l}\text { Finanse globalne } \\
\text { i międzynarodowe }\end{array}$ & $\begin{array}{l}\text { - Ugrupowania integracyjne } \\
\text { - Państwa narodowe } \\
\text { - Korporacje transnarodowe }\end{array}$ \\
\hline $\begin{array}{l}\text { Finanse publiczne } \\
\text { (rządowe) }\end{array}$ & $\begin{array}{l}\text { - Państwa (budżety centralne, systemy podatkowe, } \\
\text { systemy ubezpieczeń społecznych etc.) }\end{array}$ \\
\hline $\begin{array}{l}\text { Finanse samorządowe } \\
\text { (regionalne i lokalne) }\end{array}$ & $\begin{array}{l}\text { - Regiony } \\
\text { - Subregiony }\end{array}$ \\
\hline $\begin{array}{l}\text { Finanse banków } \\
\text { i parabanków }\end{array}$ & $\begin{array}{l}\text { - Banki i parabanki } \\
\text { - Produkty i usługi bankowe }\end{array}$ \\
\hline $\begin{array}{l}\text { Finanse towarzystw } \\
\text { ubezpieczeniowych }\end{array}$ & $\begin{array}{l}\text { - Towarzystwa ubezpieczeniowe } \\
\text { - Produkty ubezpieczeniowe }\end{array}$ \\
\hline $\begin{array}{l}\text { Finanse rynków } \\
\text { finansowych }\end{array}$ & $\begin{array}{l}\text { - Giełdy papierów wartościowych } \\
\text { - Instrumenty rynku pieniężnego i kapitałowego (pa- } \\
\text { piery wartościowe i inne niebędące nimi instru- } \\
\text { menty) }\end{array}$ \\
\hline Finanse przedsiębiorstw & $\begin{array}{l}\text { - Duże przedsiębiorstwa } \\
\text { - Mikro-, małe i średnie przedsiębiorstwa }\end{array}$ \\
\hline $\begin{array}{l}\text { Finanse gospodarstw } \\
\text { domowych }\end{array}$ & - Gospodarstwa domowe \\
\hline
\end{tabular}

Źródło: S. Flejterski, B. Świecka (red.), 2009, Elementy finansów i bankowości, Warszawa, s. 57.

Tabela 2. prezentuje formy handlu zagranicznego występujące na wolnym rynku oraz rynkach zorganizowanych.

Należy zaznaczyć, że w handlu zagranicznym zapłata za towar lub usługę następuje w zamian za dokumenty, wśród których należy wyróżnić m.in.:

- dokumenty finansowe (czek, weksel);

- dokumenty przewozowe (wśród nich konosament).

Po zlokalizowaniu dziedzin nadrzędnych oraz obszarów stycznych dla wybranego pola terminologicznego należy sprawdzić czy, i jakie produkty terminograficzne powstały w obrębie wskazanego zakresu tematycznego. W przypadku terminologii papierów wartościowych przeanalizowano istniejące na rynku słowniki i leksykony rosyjsko-polskie z obszaru finansów, handlu, biznesu i ekonomii. Nie odnotowano przy tym występowania na polskim rynku wydawniczym słownika ( $\mathrm{w}$ tym również słownika $\mathrm{w}$ formie tezaurusa) 
Tabela 2. Formy handlu zagranicznego

\begin{tabular}{|l|l|}
\hline Formy handlu zagranicznego & - import \\
występujące na wolnym & - eksport \\
rynku & - handel tranzytowy \\
& - obrót uszlachetniający i reparacyjny \\
& - obrót licencjami i know-how \\
& - franchising \\
& - leasing \\
& - transakcje wiązane, kompensacyjne \\
& i barterowe \\
& - obrót projektami inwestycyjnymi \\
& - inwestycje bezpośrednie \\
\hline Formy handlu zagranicznego & - giełdy: towarowe, usług, frachtów, \\
występujące na rynkach & ubezpieczeń, usług transakcyjnych \\
zorganizowanych & (na giełdach towarowych obraca się \\
& m.in. dowodami składowymi $\left.{ }^{2}\right)$ \\
& - aukcje \\
& - targi \\
& przetargi \\
\hline
\end{tabular}

Źródło: opracowanie własne na podstawie J. Rymarczyk (red.), 2012, Handel zagraniczny. Organizacja i technika, Warszawa, s. 17-18.

polsko-rosyjskiego bądź rosyjsko-polskiego dotyczącego wyłącznie terminologii papierów wartościowych. Podczas analizy wzięto pod uwagę następujące charakterystyki słowników terminologicznych: liczba artykułów hasłowych; sposób porządkowania zasobu terminologicznego; technika opracowania zasobu terminologicznego; obecność bibliografii, indeksów, załączników; obecność akcentu; obecność informacji gramatycznej; obecność definicji. Ponadto podjęto starania, by sprawdzić, w jakim stopniu w danym słowniku została odzwierciedlona terminologia papierów wartościowych. W tym celu porównano zawartość artykułów hasłowych dla pięciu terminów bazowych z zakresu papierów wartościowych (akcja, czek, obligacja, papiery wartościowe, weksel) w poddanych analizie słownikach. Wyniki zobrazowano w postaci takich określeń, jak: wyczerpujacy, wybiórczy, minimalny. Sformułowanie wyczerpujacy odnosi się do słowników, w których po wskazanych terminach bazowych występują długie gniazda terminologiczne (od 15 terminów wielokomponentowych). Z kolei oznaczenie wybiórczy dotyczy słowników,

$2 \mathrm{~W}$ polskim prawie dowód składowy został zniesiony jako instytucja prawna zgodnie z Ustawa o ograniczaniu barier administracyjnych dla obywateli i przedsiębiorców z dnia 25 marca 2011 r., ze skutkiem na 1 lipca 2011 r. 
Tabela 3. Analiza parametryczna słowników rosyjsko-polskich zawierających terminologię papierów wartościowych

\begin{tabular}{|c|c|c|c|c|c|c|c|c|c|}
\hline autor $(\text { rok })^{3}$ & $\begin{array}{l}\text { liczba } \\
\text { haseł }\end{array}$ & $\begin{array}{c}\text { sposób } \\
\text { porządkowania }\end{array}$ & $\begin{array}{c}\text { technika } \\
\text { opracowania } \\
\text { zas. }\end{array}$ & $\begin{array}{l}\text { biblio- } \\
\text { grafia }\end{array}$ & indeks & $\begin{array}{l}\text { załaccz- } \\
\text { niki }\end{array}$ & akcent & \begin{tabular}{|l} 
inf. \\
grama- \\
tyczna
\end{tabular} & $\begin{array}{c}\text { stopień } \\
\text { odzwierciedlenia } \\
\text { terminologii PW }\end{array}$ \\
\hline E. Cichowski (1992) & 5000 & alfabetyczno-gniazdowy & glosariusz & - & - & + & - & + & minimalny \\
\hline R. Hajczuk [et. al.] (1992) & 6000 & alfabetyczno-gniazdowy & glosariusz & + & - & - & - & - & wybiórczy \\
\hline J. Grabowska (1994) & 10000 & alfabetyczno-gniazdowy & glosariusz & - & - & + & + & + & wyczerpujący \\
\hline $\begin{array}{l}\text { L. Jochym-Kuszlikowa } \\
\text { [et al.] (1996) }\end{array}$ & 28000 & alfabetyczno-gniazdowy & glosariusz & + & - & - & + & + & wyczerpujący \\
\hline $\begin{array}{l}\text { J. F. Nosowicz [et. al.] } \\
\text { (1997) }\end{array}$ & 2200 & alfabetyczno-gniazdowy & $\mid \begin{array}{c}\text { słownik } \\
\text { terminologiczny }\end{array}$ & - & - & - & - & + & wybiórczy \\
\hline $\begin{array}{l}\text { J. Lubocha-Kruglik } \\
\text { [et. al.] (2001) }\end{array}$ & 5500 & tematyczno-alfabetyczny & glosariusz & - & + & - & + & - & wybiórczy \\
\hline $\begin{array}{l}\text { N. Celer, S. Domagalski } \\
(2003)\end{array}$ & 22000 & alfabetyczny & glosariusz & - & - & + & - & - & minimalny \\
\hline $\begin{array}{l}\text { J. Lukszyn, W. Zmarzer } \\
(2004)\end{array}$ & 465 & tematyczno-alfabetyczny & $\begin{array}{c}\text { słownik } \\
\text { terminologiczny }\end{array}$ & - & + & - & + & - & wyczerpujący \\
\hline P. Kapusta (2009) & 18000 & alfabetyczno-gniazdowy & glosariusz & - & - & - & - & - & minimalny \\
\hline $\begin{array}{l}\text { L. Jochym-Kuszlikowa } \\
\text { [et. al.] (2009) }\end{array}$ & 29000 & alfabetyczno-gniazdowy & glosariusz & + & - & + & + & + & wyczerpujący \\
\hline
\end{tabular}

${ }^{3}$ Pełne dane bibliograficzne słowników poddanych analizie znajdują się w załączniku do niniejszego artykułu. 
w których występuje średnia ilość terminów wielokomponentowych tworzących dane gniazdo terminologiczne (od 5 do 15). Określenie minimalny zarezerwowano dla tych słowników, w których obok wyodrębnionych terminów bazowych występuje poniżej 5 terminów w gnieździe terminologicznym.

Jak wynika z tabeli 3 aż cztery z dziesięciu poddanych analizie słowników zaklasyfikowano do słowników wyczerpujących. Należy jednak zwrócić uwagę na fakt, że wskazane prace terminograficzne są słownikami, w których przy konstruowaniu artykułów hasłowych zastosowano technikę separowania, co oznacza, że każdy artykuł hasłowy ma formę odrębnego wywodu naukowego. Korzystanie z tego typu słowników zakłada samodzielne odtwarzanie danego systemu konceptualnego, co często przerasta możliwości wielu użytkowników, którzy nie są specjalistami w danej dziedzinie. Co więcej, należy zauważyć, że wszystkie poddane analizie słowniki terminologiczne odzwierciedlają terminologię papierów wartościowych, które funkcjonują na polskich rynkach: finansowym i towarowym. W związku z tym moga one okazać się niewystarczające do zrozumienia specyfiki obrotu papierami wartościowymi w Federacji Rosyjskiej.

\section{3. Źródła zasobu terminologicznego}

Po wstępnym określeniu zakresu tematycznego słownika należy rozpoczać gromadzenie materiałów niezbędnych do jego skonstruowania. Według Polskiej Normy (1995) korpus tekstów jako nośników aktualnej terminologii mogą stanowić:

1) dokumenty urzędowe (ustawy, przepisy, inne dokumenty normatywne);

2) periodyki, rozprawy naukowe, podręczniki;

3) dokumenty o zasięgu branżowym (instrukcje, standardy terminologiczne);

4) wypowiedzi ekspertów;

5) słowniki terminologiczne i encyklopedie [Lukszyn, Zmarzer 2006, 134; Leski 1978, 45-46].

Zgodnie z definicją zaproponowaną przez S. Gruczę „korpus tekstowy to każdy zbiór pisanych lub mówionych tekstów sformułowanych w określonym języku (językach), które zostały zebrane i wybrane według określonych kryteriów" [Grucza 2008, 204]. Korpus wykorzystany do ekscerpcji terminologii dla konstruowanego słownika dydaktycznego charakteryzuje się następującymi cechami: 1) specjalny (obejmujący wybrane rodzaje tekstów); 2) sporządzony na bazie tekstów pisanych; 3) wielojęzyczny, złożony z tekstów paralelnych, nie będących własnymi translatami; 4) statyczny (z za- 
mkniętym wyborem tekstów); 5) synchroniczny; 6) zawierający pełne teksty [Łukasik 2007, 26].

W przypadku terminologii papierów wartościowych najbardziej aktualnymi tekstami terminonośnymi, które należy wziąć pod uwagę w pierwszej kolejności, są ustawy. Poniżej przedstawiono akty normatywne regulujące obrót papierami wartościowymi w Federacji Rosyjskiej, z których wyekscerpowano większość terminów znajdujących się w słowniku ${ }^{4}$. Akty normatywne należą do tekstów skodyfikowanych cechujących się ustaloną strukturą w formie uporządkowanego ciągu rekwizytów. Akty normatywne pogrupowane są na określone części składowe: artykuły, rozdziały, działy, tytuły itp. Artykuły z kolei można podzielić na ustępy, punkty, litery, tiret (w przypadku polskich aktów normatywnych). Z kolei w rosyjskim ustawodawstwie artykuł można podzielić na paragrafy, punkty, podpunkty.

W przypadku aktów normatywnych dotyczących papierów wartościowych szczególnym miejscem, w którym zazwyczaj zebrana jest oraz zdefiniowana większość jednostek terminologicznych są tzw. przepisy ogólne, znajdujące się $\mathrm{w}$ dziale pierwszym danego aktu normatywnego. Ekscerpcję jednostek terminologicznych z rosyjskich aktów normatywnych ułatwia również fakt, że każdy artykuł rozpoczyna się od nagłówka, który zazwyczaj stanowi termin wielokomponentowy używany w dalszej części artykułu.

Tabela 4. Akty normatywne regulujące obrót papierami wartościowymi w Federacji Rosyjskiej

\begin{tabular}{|c|c|}
\hline Papier wartościowy & $\begin{array}{l}\text { Akt normatywny regulujaccy obrót danego papieru } \\
\text { wartościowego w Federacji Rosyjskiej }\end{array}$ \\
\hline акция & $\begin{array}{l}\text { Федеральный закон "О рынке ценных бумаг" от } 22 \text { апреля } \\
1996 \text { г. N 39-Ф3 ст. 2; 16; Федеральный закон "Об акцио- } \\
\text { нерных обществах" от } 26 \text { декабря } 1995 \text { г. N 208-Ф3 ст. } 25\end{array}$ \\
\hline вексель & $\begin{array}{l}\text { Положение о переводном и простом векселе от } 7 \text { августа } \\
1937 \text { г. N 104/1341; Федеральный закон "О переводном } \\
\text { и простом векселе" от } 11 \text { марта } 1997 \text { г. N 48-Ф3 }\end{array}$ \\
\hline $\begin{array}{l}\text { двойное складское } \\
\text { свидетельство }\end{array}$ & $\begin{array}{l}\text { Федеральный закон "О двойных и простых складских сви- } \\
\text { детельствах" от } 12 \text { апреля } 2001 \text { г. N 1364-III ГД }\end{array}$ \\
\hline
\end{tabular}

4 W przypadku niektórych aktów normatywnych, takich jak np. Гражданский кодекс Российской Федерации (Kodeks cywilny Federacji Rosyjskiej) bądź Кодекс торгового мореплавания Российской Федерации (Kodeks morski Federacji Rosyjskiej), rejestracja jednostek terminologicznych w nich odzwierciedlonych przeprowadzona została w ramach konkretnych artykułów z poszczególnych rozdziałów dotyczących papierów wartościowych. 


\begin{tabular}{|c|c|}
\hline Papier wartościowy & $\begin{array}{c}\text { Akt normatywny regulujaccy obrót danego papieru } \\
\text { wartościowego w Federacji Rosyjskiej }\end{array}$ \\
\hline $\begin{array}{l}\text { депозитный серти- } \\
\text { фикат }\end{array}$ & $\begin{array}{l}\text { Гражданский Кодекс Российской Федерации от } 30 \text { ноября } \\
1994 \text { г. N 51-Ф ст. } 844\end{array}$ \\
\hline закладная & $\begin{array}{l}\text { Федеральный закон "Об ипотеке (залоге недвижимости)" } \\
\text { от } 16 \text { июля } 1998 \text { г. N 102-ФЗ ст. } 13\end{array}$ \\
\hline $\begin{array}{l}\text { инвестиционный } \\
\text { пай }\end{array}$ & $\begin{array}{l}\text { Федеральный закон "Об инвестиционных фондах" от } 29 \text { но- } \\
\text { ября } 2001 \text { г. N 156-Ф3 ст. } 14\end{array}$ \\
\hline $\begin{array}{l}\text { ипотечный серти- } \\
\text { фикат участия }\end{array}$ & $\begin{array}{l}\text { Федеральный закон "Об ипотечных ценных бумагах" от } \\
11 \text { ноября } 2003 \text { г. N 152-Ф3 ст. 2; 17-30 }\end{array}$ \\
\hline коносамент & $\begin{array}{l}\text { Брюссельская конвенция } 1924 \text { г., "Об унификации неко- } \\
\text { торых правил о коносаменте (Гаагские правила)"; Кодекс } \\
\text { торгового мореплавания Российской Федерации от } 30 \text { апре- } \\
\text { ля } 1999 \text { г. N 81-ФЗ ст. } 117 ; 142-149\end{array}$ \\
\hline облигация & $\begin{array}{l}\text { Федеральный закон "О рынке ценных бумаг” от } 22 \text { апреля } \\
1996 \text { г. N 39-Ф3 ст. } 2 ; 27.2-27.5\end{array}$ \\
\hline опцион эмитента & $\begin{array}{l}\text { Федеральный закон “О рынке ценных бумаг” от } 22 \text { апреля } \\
1996 \text { г. N 39-Ф3 ст. 2; } 27.1\end{array}$ \\
\hline $\begin{array}{l}\text { простое складское } \\
\text { свидетельство }\end{array}$ & $\begin{array}{l}\text { Федеральный закон "О двойных и простых складских сви- } \\
\text { детельствах" от } 12 \text { апреля } 2001 \text { г. N 1364-III ГД }\end{array}$ \\
\hline $\begin{array}{l}\text { российская депози- } \\
\text { тарная расписка }\end{array}$ & $\begin{array}{l}\text { Федеральный закон “О рынке ценных бумаг” от } 22 \text { апреля } \\
1996 \text { г. N 39-Ф3 ст. 2; 27.5-3 }\end{array}$ \\
\hline $\begin{array}{l}\text { сберегательная } \\
\text { книжка на } \\
\text { предъявителя }\end{array}$ & $\begin{array}{l}\text { Гражданский Кодекс Российской Федерации от } 30 \text { ноября } \\
1994 \text { г. N 51-Ф ст. } 843\end{array}$ \\
\hline $\begin{array}{l}\text { сберегательный } \\
\text { сертификат }\end{array}$ & $\begin{array}{l}\text { Гражданский Кодекс Российской Федерации от } 30 \text { ноября } \\
1994 \text { г. N 51-Ф ст. } 844\end{array}$ \\
\hline чек & $\begin{array}{l}\text { Гражданский Кодекс Российской Федерации от } 30 \text { ноября } \\
1994 \text { г. N 51-Ф ст. 877-885 }\end{array}$ \\
\hline
\end{tabular}

Pozostałymi źródłami terminologii w konstruowanym słowniku dydaktycznym są podręczniki akademickie dotyczące papierów wartościowych oraz rynku papierów wartościowych, słowniki terminologiczne oraz encyklopedie, w których odzwierciedlona została analizowana terminologia. Każdy zaakceptowany tekst, który znalazł się w korpusie, został wnikliwie przeanalizowany pod kątem występujących w nim jednostek terminologicznych na- 
leżących do pola terminologicznego papierów wartościowych. Według standardów ISO szczególnie ważnymi obszarami identyfikacji terminów są: tytuł; abstrakt lub synopsa; spis treści; wprowadzenie, zdania początkowe rozdziałów i ustępów, zakończenie; objaśnienia, ilustracje, wykresy, tabele, legendy [ISO 5963, 1985, 2].

\section{Makro- i mikrostruktura rosyjsko-polskiego słownika dydaktycznego papierów wartościowych}

Słownik terminologiczny stanowi produkt pracy terminograficznej opartej na następujących zasadach: zasadzie adekwatnego ograniczenia zbio$\mathrm{ru}$ terminologicznego $\mathrm{w}$ słowniku, zasadzie systematyzacji oraz zasadzie międzynarodowej harmonizacji terminologii $\mathrm{w}$ słowniku [Lukszyn, Zmarzer 2006, 134].

Zasada adekwatnego ograniczenia zbioru terminologicznego sprowadza sie do ustalenia korpusu niezbędnych tekstów będących nośnikami aktualnej terminologii. Procedura ograniczenia zasobu terminologicznego w dalszej kolejności obejmuje sporządzenie roboczej kartoteki oraz wyodrębnienie w jej składzie terminologii ogólnonaukowej, interdyscyplinarnej i branżowej [STP 2005, 158]. W przypadku terminologii występującej w konstruowanym słowniku dydaktycznym zrezygnowano z terminów należących do pól stycznych z polem papierów wartościowych. Kolejnym krokiem w ramach tej zasady jest dobór kryteriów, w oparciu o które następuje selekcja terminów. Według S. Grineva do takich kryteriów należy zaliczyć: 1) ważność (wartość semantyczną terminu); 2) użyteczność (częstotliwość użycia); 3) przynależność tematyczną terminu; 4) systemowość terminu; 5) zdolność słowotwórczą terminu 6) pełne ujęcie w słowniku terminów przynależących do danego obszaru tematycznego; 7) synchroniczność terminu; 8) normatywność terminu; 9) łączliwość terminu [Гринев 2008, 96]. Ograniczenie ilości terminów w konstruowanym słowniku dydaktycznym zostało dokonane w oparciu o następujące wytyczne:

- częstotliwość występowania danych terminów w zgromadzonym korpusie tekstów z zakresu literatury przedmiotu;

- systemowość (rola jaką pełni dane pojęcie w systemie konceptualnym analizowanego zbioru terminologicznego).

Dodatkowo w celu ograniczenia zasobu terminologicznego terminy zostały uporządkowane $\mathrm{w}$ formie hermetycznego tezaurusa uwzględniającego najbardziej istotne relacje pomiędzy nimi. Określenia relacji semantycznych pomiędzy terminami występującymi w polu terminologicznym papierów war- 
tościowych dokonano poprzez nałożenie na tę terminologię kwadratu terminologicznego [STP 2005, 60; Lukszyn, Zmarzer 2006, 42]. Należy zaznaczyć, że prawidłowe odtworzenie struktury sieci semantycznej stanowi niezbędny warunek prawidłowego konstruowania terminograficznego. Ograniczeniu zasobu terminologicznego posłużyło również modułowe ułożenie terminologii w słowniku - podział pola terminologicznego papierów wartościowych na mikropola zgodnie z procesem dydaktycznym.

Zasada systematyzacji sprowadza się do uporządkowania badanego pola terminologicznego w formie słownika, na co składają się następujące czynności: wyodrębnienie bazowych jednostek terminologicznych oraz zbudowanych na ich podstawie serii terminologicznych; przyporządkowanie odpowiednich typów definicji dla poszczególnych serii; określenie struktury paradygmatów terminologicznych; ustalenie mikrostruktury słownika. Należy również zwrócić uwagę na fakt, że systematyzacja zbioru terminologicznego może odbywać się w oparciu o różnego typu parametry takie jak: językowe, semiotyczne oraz konceptualne [Lukszyn, Zmarzer 2006, 137-141]. Zastosowanie systematyzacji w oparciu o konkretny typ parametrów powoduje uzyskanie szczególnego typu słownika terminologicznego. W przypadku konstruowanego słownika zastosowano systematyzację w oparciu o parametry językowe oraz konceptualne. Rezultatem przyjęcia za podstawę systematyzacji parametrów językowych jest uzyskanie systemu naturalnego, który w przypadku słownika papierów wartościowych zawiera informacje o takich zjawiskach w obrębie słownika jak: synonimia, antonimia, hipo- oraz hiperonimia. Z kolei zastosowanie systematyzacji $\mathrm{w}$ oparciu o parametry konceptualne powoduje uzyskanie systemu kognitywnego zawierającego informacje o typie składni logicznej. W rezultacie zastosowania dwóch grup parametrów uzyskujemy system mieszany. Jak wspomniano powyżej, konstruowany słownik dydaktyczny ma budowę modułową i składa się z następujących części:

1) wstęp (w języku rosyjskim i polskim);

2) struktura słownika (opis makro- oraz mikrostruktury w języku rosyjskim i polskim);

3) znaki umowne oraz skróty zastosowane w słowniku (w języku rosyjskim i polskim);

4) spis skrótów przyjętych dla oznaczenia źródeł terminologii;

5) bibliografia uzupełniająca;

6) prezentacje graficzne terminologii znajdującej się w słowniku;

7) słownik rosyjsko-polski składający się z 3 modułów: papiery wartościowe, finanse, handel;

8) indeks terminów rosyjskich; 
9) indeks polskich odpowiedników;

10) aneks w formie rosyjskich blankietów papierów wartościowych.

Powyższe dane wskazuję, że w zasadzie wszystkie wyróżnione części składowe słownika wpływają na jego dydaktyczny charakter.

Podczas tworzenia słownika kierowano się zasada symetrii, która w przypadku ogólnej koncepcji słownika oznacza symetryczne ułożenie leksyki oraz adekwatny system odsyłaczy. Aby tego dokonać podzielono wyekscerpowane terminy na 3 moduły (klasy tematyczne): papiery wartościowe (zawierający 53 terminy); finanse (58 terminów); handel (68 terminów). W ramach 3 modułów podstawowych słownika zastosowano alfabetyczny układ artykułów hasłowych. Każdemu artykułowi hasłowemu przyporządkowano literę(-y) oznaczającą(-e) dany moduł oraz numer porządkowy, co pozwala użytkownikowi na szybkie odnalezienie interesującego go terminu.

Jeśli chodzi o mikrostrukturę słownika, to artykuł hasłowy składa się z następujących elementów:

1) litera(-y) oznaczająca przynależność do konkretnego modułu oraz numer porządkowy hasła;

2) termin w języku rosyjskim z zaznaczonym akcentem;

3) odpowiednik(-i) w języku polskim poprzedzony(-e) symbolem PL (w przypadku braku odpowiednika wprowadzono tłumaczenie autorskie terminu rosyjskiego, które oznaczono literą A.; w przypadku niektórych terminów podano ekwiwalent funkcjonalny, który oznaczono symbolem $\| ; \mathrm{w}$ przypadku niektórych terminów podano ekwiwalenty częściowe, które oznaczono symbolem $\approx ; \mathrm{w}$ przypadku występowania kilku odpowiedników w języku polskim podano je w następującej kolejności: od najczęściej stosowanych w tekstach z zakresu literatury przedmiotu, do rzadziej używanych);

4) definicje terminów rosyjskich i polskich odpowiedników (w przeważającej części artykułów hasłowych występuje definicja predykatywna; w przypadku większości artykułów hasłowych poniżej definicji znajdują się tzw. informacje dodatkowe ujęte w nawiasie klamrowym, które razem z definicją predykatywną tworzą definicję intensjonalną);

5) źródła definicji terminów (podane w nawiasach kwadratowych w formie skrótu);

6) mikrotezaurus, w ramach którego wyróżniono następujące typy terminów (w nawiasach podano symbole zastosowane w celu ich oznaczenia):

a) termin rodzajowy - termin nadrzędny w stosunku do terminu hasłowego $^{5}(\uparrow)$;

$5 \mathrm{~W}$ przypadku pola terminologicznego papierów wartościowych mamy do czynienia 
b) termin gatunkowy - termin podrzędny w stosunku do terminu hasłowego $(\downarrow)$;

c) termin „całość" - termin górny w stosunku do terminu hasłowego oznaczający całość $(\vdash)$;

d) termin „częśćc - termin dolny w stosunku do terminu hasłowego oznaczający część ( $\ulcorner$ );

e) termin komplementarny - termin współrzędny zależny od terminu hasłowego $(\rightarrow)$;

f) termin przeciwstawny - termin współrzędny przeciwstawny do terminu hasłowego $(\leftrightarrow)$;

g) termin skojarzony - różnego rodzaju terminy powiązane relacjami asocjacyjnymi poza terminami komplementarnymi oraz terminami przeciwstawnymi $(\sim)$;

h) termin synonimiczny - termin używany w tekstach specjalistycznych zamiast terminu hasłowego ( $\equiv$ ).

Postać graficzna artykułu hasłowego przedstawia się w następujący sposób:

\section{ЦБ. 50. ценные бумагии}

Документы, соответствующие установленным законом требованиям и удостоверяющие обязательственные и иные права, осуществление или передача которых возможны только при предъявлении таких документов. Ценными бумагами признаются также обязательственные и иные права, которые закреплены в решении о выпуске или ином акте лица, выпустившего ценные бумаги в соответствии с требованиями закона, и осуществление и передача которых возможны только с соблюдением правил учёtа этих прав.

$\{$ Ценными бумагами являются акция, вексель, депозитный сертификат, закладная, инвестиционный пай паевого инвестиционного фонда, ипотечный сертификат участия, коносамент, облигация, чек, двойное складское свидетельство, опцион эмитента, простое складское свидетельство, российская депозитарная расписка, сберегательная книжка на предъявителя, сберегательный сертификат.\}

\section{PL: papiery wartościowe}

Dokumenty lub zapisy w systemie informatycznym na rachunku papierów wartościowych, stwierdzające określone prawa majątkowe, których realizacja jest możliwa jedynie na podstawie okazania, udowodnienia własności, przekazania innej osobie lub zwrotu wystawcy tych dokumentów.

\{Wyłącznie posiadacz papierów wartościowych może realizować wynikające z nich prawa. W Polsce do papierów wartościowych należą takie walory jak: akcja, prawo poboru, prawo do akcji, warrant subskrypcyjny, kwit depozytowy, obligacja, list zastawny, certyfikat inwestycyjny, weksel, czek, konosament, dowód składowy, bon skarbowy i inne papiery inkorporujacce prawa majątkowe i wyemitowane na podstawie właściwych przepisów prawa polskiego.\}

z tzw. relacjami polihierarchicznymi w obrębie relacji rodzajowo-gatunkowej, co w praktyce oznacza ujęcie w tezaurusie kilku deskryptorów rodzajowych $\mathrm{w}$ stosunku do jednego deskryptora gatunkowego. 
[1] [ГК РФ, ст. 142]

$\downarrow$ бездокументарные ценные бумаги; бессрочные ценные бумаги; вторичные ценные бумаги; государственные ценные бумаги; документарные ценные бумаги; долговые ценные бумаги; долевые ценные бумаги; именные ценные бумаги; инвестиционные ценные бумаги; ипотечные ценные бумаги; коммерческие ценные бумаги; негосударственные ценные бумаги; неинвестиционные ценные бумаги; неэмиссионные ценные бумаги; ордерные ценные бумаги; первичные ценные бумаги; предъявительские ценные бумаги; срочные ценные бумаги; фондовые ценные бумаги; эмиссионные ценные бумаги

$\longrightarrow$ владелец ценных бумаг; эмитент ценных бумаг

обращение ценных бумаг; портфель ценных бумаг; рынок ценных бумаг
[DD $[\mathrm{RPW}$, s. 13; UOIF, art. 3]

$\downarrow$ zdematerializowane papiery wartościowe; bezterminowe papiery wartościowe; pochodne papiery wartościowe; państwowe papiery wartościowe; papiery wartościowe w formie dokumentu; dłużne papiery wartościowe; udziałowe papiery wartościowe; imienne papiery wartościowe; lokacyjne papiery wartościowe; hipoteczne papiery wartościowe; towarowe papiery wartościowe; niepaństwowe papiery wartościowe; papiery wartościowe o charakterze rozliczeniowym; nieemisyjne papiery wartościowe; papiery wartościowe na zlecenie; pierwotne papiery wartościowe; papiery wartościowe na okaziciela; papiery wartościowe o określonym terminie wykupu; giełdowe papiery wartościowe; emisyjne papiery wartościowe

$\rightarrow$ posiadacz papierów wartościowych; emitent papierów wartościowych

$\sim$ obrót papierami wartościowymi; portfel papierów wartościowych; rynek papierów wartościowych

Jak można zauważyć, w przypadku terminu иеннье бумаги brak niektórych relacji pojęciowych, co oznacza, że dany termin nie wstępuje we wszystkie typy relacji wskazane w mikrotezaurusie. Niektóre artykuły hasłowe należą do tzw. artykułów odsyłaczy. Można je podzielić na 2 typy:

1) artykuł odsyłający do całości innego artykułu hasłowego (w takim przypadku terminem hasłowym jest synonim innego terminu hasłowego), np.

\section{T. 61. фрахтовщик см. перевозчик} PL: przewoźnik

2) artykuł odsyłający do definicji, znajdującej się w innym artykule hasłowym, np.

\begin{tabular}{|c|c|}
\hline $\begin{array}{l}\text { едъявительские це } \\
\text { ексель } \\
\text { ордерный вексель }\end{array}$ & $\begin{array}{l}\text { PL: weksel na okazicie } \\
\uparrow \text { weksel } \\
\leftrightarrow \text { weksel na zlecenie }\end{array}$ \\
\hline
\end{tabular}

Zasade harmonizacji terminologii można rozpatrywać na dwóch płaszczyznach: wewnętrznej i zewnętrznej. Harmonizacja wewnętrzna w przypadku konstruowanego słownika obejmuje unifikację definicji oraz stosowanie ujednoliconych formuł językowych. Ponadto harmonizacja wewnętrzna 
przejawia się we wskazaniu wzajemnych powiązań między terminami występującymi w słowniku w ramach poszczególnych modułów. Z kolei harmonizacja zewnętrzna oznacza kojarzenie narodowego leksykonu terminologicznego z prymarnym systemem terminologicznym, co w praktyce sprowadza się do uwzględnienia w słowniku ekwiwalentów z języków światowych, które posiadają rozbudowane zasoby słownictwa specjalistycznego w danej dziedzinie. W związku z tym w słowniku można (ale nie jest to obowiązkowe) uwzględniać ekwiwalenty obcojęzyczne w takich językach, jak: angielski, niemiecki, francuski, rosyjski, hiszpański czy włoski [STP 2005, 34]. Dzięki zestawieniu rosyjskich terminów z zakresu papierów wartościowych z ich polskimi odpowiednikami ujawniono brak odpowiedników w języku polskim niektórych terminów rosyjskich (są to tzw. luki terminologiczne), a także wskazano odpowiedniki funkcjonalne oraz częściowe.

Kontynuacją etapu systematyzacji oraz harmonizacji terminologii $\mathrm{w}$ słowniku jest zapis danych terminologicznych w optymalnej i ostatecznej postaci, a także ostateczna korekta danych terminologicznych [Nagórka 2008, 203]. W przypadku rosyjsko-polskiego słownika dydaktycznego papierów wartościowych kwestiami rozważanymi na tym etapie były techniczne aspekty zapisu jednostek terminologicznych, takie jak: szyk w rosyjskich terminach wielokomponentowych, wybór liczby pojedynczej lub mnogiej, sprawdzenie ekwiwalentów w języku polskim. Wymienione kwestie zostały rozwiązane $\mathrm{w}$ następujący sposób: w terminach wielokomponentowych zachowano szyk języka rosyjskiego. W przypadku terminu ченнье бумаги, a także terminów powiązanych z nim (stanowiących serię terminologiczną) zastosowano liczbę mnogą, natomiast w przypadku nazw poszczególnych papierów wartościowych użyto liczby pojedynczej. Korekta polskich ekwiwalentów sprowadzona została do sprawdzenia obustronności relacji pomiędzy terminami hasłowymi i ich odpowiednikami.

Po zakończeniu prac związanych z konstruowaniem siatki haseł tezaurusa przystąpiono do przygotowania prezentacji graficznej terminologii ujętej w słowniku. Konstruowany moduł graficzny uwzględnia pięć rodzajów relacji pojęciowych, takich jak: relacja generyczna; relacja inkluzji; relacja przeciwstawności; relacja komplementarności; relacja asocjacji. W celu przedstawienia typów relacji semantycznych przygotowano ich oznaczenia w formie linii i strzałek [por. Nagórka 2011, 151]:

$\longrightarrow$ taksonomia (rodzaj - gatunek)

$\longrightarrow$ inkluzja (całość - część)

$\longleftrightarrow$ kontradyktoryjność (A jest przeciwstawne B)

komplementarność (A towarzyszy B)

-..- asocjacja (A kojarzy się z B) 
Ostatnią fazą kończącą pracę nad tezaurusem jest przygotowanie go do wydania w formacie tradycyjnym (oraz/lub w formacie elektronicznym). Niezależnie od formatu wydawniczego należy zadbać o szatę graficzną słownika np. poprzez dobór odpowiednich czcionek, znaków graficznych oraz kolorystyki. Należy pamiętać o tym, że w momencie publikacji tezaurusa siatka haseł może się okazać względnie nieaktualna, w związku z czym kartoteka słownika powinna być uzupełniana co kilka lat.

\section{Wnioski}

1. Prymarnym celem konstruowania specjalistycznych słowników dydaktycznych jest ich zastosowanie w procesie nauczania i uczenia się danego języka specjalistycznego.

2. Budowę makro- oraz mikrostruktury słownika należy uzależnić w pierwszej kolejności od typu adresata oraz tematyki słownika.

3. Etapy konstruowania specjalistycznego słownika dydaktycznego sprowadzają się do:

a) określenia adresata oraz zakresu tematycznego słownika;

b) analizy istniejących na rynku wydawniczym produktów pracy terminograficznej, powstałych w obrębie zakresu tematycznego słownika;

c) wskazania źródeł zasobu terminologicznego dla słownika;

d) określenia makro- i mikrostruktury słownika z uwzględnieniem zasad stosowanych w praktyce terminograficznej, a w szczególności zasady symetrii;

e) korekty i zapisu danych terminologicznych w postaci ostatecznej;

f) przygotowania prezentacji graficznej (oraz/lub systematycznej) terminologii objętej słownikiem;

g) wydania słownika $\mathrm{w}$ formacie tradycyjnym (oraz/lub elektronicznym).

4. Istniejące na polskim rynku wydawniczym słowniki terminologiczne odzwierciedlają terminologię papierów wartościowych, które funkcjonują na polskich rynkach: finansowym i towarowym, przez co mogą one okazać się niewystarczające do zrozumienia specyfiki obrotu papierami wartościowymi w Federacji Rosyjskiej. W związku z tym założenie skonstruowania rosyjsko-polskiego tezaurusa z zakresu papierów wartościowych występujących w Federacji Rosyjskiej jest projektem, który wypełni lukę na liście profesjonalnie sporządzonych dwujęzycznych dydaktycznych słowników terminologicznych. 


\section{Bibliografia}

Flejterski S., Świecka B. (red.), 2009, Elementy finansów i bankowości, Warszawa. Grucza S., 2008, O konieczności tworzenia korpusów tekstów specjalistycznych, [w:] Podstawy technolingwistyki, I, red. J. Lukszyn, Warszawa, s. 197-224.

Karpiński Ł., 2008, Zarys leksykografii terminologicznej, Warszawa.

Leski K., 1978, Zasady budowy tezaurusów, Warszawa.

Lukszyn J., Zmarzer W., 2006, Teoretyczne podstawy terminologii, Warszawa.

Łukasik M., 2007, Angielsko-polskie $i$ polsko-angielskie słowniki specjalistyczne (1990-2006). Analiza terminograficzna, Warszawa.

Łukasik M., 2007, Narzędzia lingwistyki korpusowej w warsztacie terminologa, terminografa i tłumacza tekstów specjalistycznych (cz. 1), [w:] Debiuty naukowe I. Wiedza - korpus - stownik, red. M. Łukasik, Warszawa, s. 23-47.

Nagórka P., 2008, Metodyka budowy tezaurusa terminologii branżowej, [w:] Języki specjalistyczne 8. Kulturowy i leksykograficzny obraz języków specjalistycznych, red. J. Lukszyn, Ł. Karpiński, Warszawa, s. 194-205.

Nagórka P., 2011, Tezaurus terminologii branżowej jako tekst edukacyjny, niepublikowana praca doktorska, wykonana pod kierunkiem naukowym prof. dr. hab. J. Lukszyna, Warszawa.

Rymarczyk J. (red.), 2012, Handel zagraniczny. Organizacja i technika, Warszawa. $\mathrm{STP}=$ Lukszyn J. (red), 2005, Języki specjalistyczne. Stownik terminologii przedmiotowej, Warszawa.

Герд А. С., 1986, Основь научно-технической лексикографии, Ленинград.

Гринев-Гриневич С. В., 2008, Введение в терминографию, Москва.

Дубичинский В. В., 2008, Лексикография русского языка, Москва.

Кудашев И. С., 2007, Проектирование переводческих словарей специальной лексики, Хельсинки.

ISO 5963, 1985, Documentation - methods for examining documents, determining their subjects, and selecting indexing terms, first edition - 1985-12-01, UDC 001.815, 5 pages, ISO/TC 46.

\section{Załącznik. Lista przeanalizowanych słowników}

Cichowski E., 1992, Słownik polsko-rosyjski, rosyjsko-polski dla biznesmenów, Bydgoszcz.

Domagalski S., Celer N., 2003, Stownik biznesu rosyjsko-polski polsko-rosyjski, Warszawa.

Grabowska J., 1994, Mały praktyczny stownik biznesmena rosyjsko-polski, polsko-rosyjski, Warszawa.

Hajczuk R., Nosowicz J. F., Ruśkowski E., 1992, Kieszonkowy polsko-rosyjski i rosyjsko-polski słownik handlowy, Białystok. 
Jochym-Kuszlikowa L., Kossakowska E., 1996, Rosyjsko-polski stownik handlowy, Warszawa - Kraków.

Jochym-Kuszlikowa L., Kossakowska E., 2009, Stownik rosyjsko-polski. Biznes i gospodarka, Warszawa.

Kapusta P., 2009, Stownik biznesmena rosyjsko-polski, Kraków.

Lubocha-Kruglik J., Zobek T., Zych A., 2001, Ekonomia. Rosyjsko-polski stownik tematyczny, Warszawa.

Lukszyn J., Zmarzer W. (red.), 2004, Podręczny polsko-rosyjski słownik biznesmena, Warszawa.

Nosowicz J. F., Dacewicz L. (red.), 1997, Leksykon terminologii prawniczej i ekonomicznej polsko-rosyjski, rosyjsko-polski, Białystok.

\title{
PRINCIPLES OF COMPILING A SPECIALIST DICTONARY \\ FOR DIDACTIC PURPOSES \\ (ON MATERIAL OF SECURITIES TERMINOLOGY)
}

\author{
S U M M A R Y
}

The aim of the following article is to present stages of compiling a specialist dictionary for didactic puropses with the focus on securities terminology. The article is divided into three parts. The first part is devoted to dictionary users and thematic scope of the constructed dictionary. It also presents the analysis of existing Russian-Polish terminological dictionaries of securities. The second part deals with materials for the dictionary that has been taken from various sources such as: legal acts, academic textbooks, dictionaries and encyclopedias. The final part presents the macro- and microstructure of Russian-Polish didactic dictionary of securities. It shows sample dictionary entries. Each entry consists of: a numer of an entry, a headword, its equivalent (or equivalents) in Polish, definition in Russian, source, commentary, a strict descriptive paradigm. The paradigm identifies six semantic relationships recognised as substantially indispensible and statistically significant. 